\title{
Advances in Watershed Management: Modeling, Monitoring, And Assessment
}

\author{
B. L. Benham, G. Yagow, I. Chaubey, K. R. Douglas-Mankin
}

\begin{abstract}
This article introduces a special collection of nine articles that address a wide range of topics all related to improving the application of watershed management planning. The articles are grouped into two broadly defined categories: modeling applications, and monitoring and assessment. The modeling application articles focus on one of two widely used watershed-scale water quality modeling packages: HSPF or SWAT. The HSPF article assesses the model's robustness when applied to watersheds across a range of topographic settings and climatic conditions. In the SWAT-related articles, researchers used the model to inform watershed management efforts in a variety of ways, including subwatershed prioritization in the context of achieving broader watershed management goals, examining the utility of applying SWAT in a watershed receiving groundwater inputs from outside the topographic watershed boundaries, and estimating the uncertainty and risk associated with meeting TMDL target loads. The monitoring and assessment articles cover such diverse topics as an examination of how best management practice effectiveness is assessed, examination of estimated nutrient loads to a reservoir where a nutrient TMDL has been developed, examination of the sources of fecal indicator bacteria in an urban watershed, and detailed accounting of issues related to flow measurements in small watersheds. The articles in this collection contribute to the body of literature that seeks to inform and advance sound watershed management planning and execution.
\end{abstract}

Keywords. Hydrologic modeling, Hydrology, Monitoring, Total maximum daily load, Water quality, Watershed.

W atershed management can be characterized as a continuous, geographically defined, integrated, collaborative process of creating and implementing plans, programs, and projects designed to sustain and enhance watershed and related ecosystem functioning. Holistic watershed management should include broad stakeholder engagement to aid in defining specific watershed management goals and related actions that support attainment of those goals. Setting watershed management goals and assessing attainment of those goals must be based on the application of sound science and appropriate tools and technology (EPA, 2008).

This article introduces and summarizes the nine articles presented in this watershed management special collection. These articles were originally presented as papers at one of two ASABE-sponsored conferences focused on watershed management and technology: TMDL 2010: Watershed Management to Improve Water Quality (in Baltimore, Maryland) and the 2010 21st Century Watershed Technology Conference (at Universidad EARTH, Costa Rica). In the U.S., the

Submitted for review in October 2011 as manuscript number SW 9448; approved for publication by the Soil \& Water Division of ASABE in November 2011.

The authors are Brian L. Benham, ASABE Member, Associate Professor, and Gene Yagow, ASABE Member, Senior Research Scientist, Department of Biological Systems Engineering, Virginia Tech, Blacksburg, Virginia; Indrajeet Chaubey, ASABE Member, Professor, Department of Agricultural and Biological Engineering, Department of Earth and Atmospheric Sciences, Purdue University, West Lafayette, Indiana; and Kyle R. Douglas-Mankin, ASABE Member, Professor, Department of Biological and Agricultural Engineering, Kansas State University, Manhattan, Kansas. Corresponding author: Brian L. Benham, Department of Biological Systems Engineering, Virginia Tech, 209 Seitz Hall, Blacksburg, VA 24060; phone: 540-231-5705; fax: 540-231-3199; e-mail: benham@vt.edu. development and implementation of watershed management efforts designed and implemented to improve and maintain water quality is often driven by the total maximum daily load (TMDL) process, as outlined in the Clean Water Act. The concept of treating watersheds as systems and attempting to manage them as such is becoming more prevalent around the world, and international watershed management efforts are often modeled on the TMDL process (EPA, 1991). A TMDL quantifies the amount, or load, of a specific pollutant that a waterbody can assimilate and still meet applicable water quality standards. Sections 303(d) and 305(b) of the Clean Water Act require that waterbodies in the U.S. be evaluated in the context of applicable water quality standards. Under the Clean Water Act, pollutant-specific TMDLs are established for impaired waterbodies. According to the U.S. EPA, pathogens, heavy metals, nutrients, sediment, oxygen depletion, and loss of biological health and diversity (resulting from habitat alteration, temperature, $\mathrm{pH}$ ) are the most common types of the more than 74,000 impairments reported by the EPA. To address these impairments, more than 46,000 TMDLs have been completed to date (EPA, 2011).

In the broadest sense, the TMDL process includes three phases:

- Impairment designation, which identifies the type, severity, and extent of the water quality impairment.

- TMDL development, which involves determination of existing and potential future pollutant loads in the watershed, linking those loads to water quality in the waterbody, and defining pollutant load reductions required to achieve applicable water quality criteria.

- Implementation, which involves putting in place control measures required to achieve water quality standards, monitoring water quality to document progress toward attainment of standards, and finally de-listing, 
i.e., removing the water body from the 303(d) and 305(b) impaired waters list, after attainment of water quality standards (Benham et al., 2011).

This collection reports on research that strives to advance the underlying science and application of modeling tools often used to inform and assess watershed management efforts such as TMDL development and implementation. The collection also includes articles that address the characterization of watersheds and best management practices (BMPs) as well as assessment opportunities and challenges and how they can impact watershed management goal setting and achievement.

\section{Modeling ApPlications}

Modeling is often an integral part of watershed management planning. Models can be used to assess and characterize the type and extent of pollution sources, to evaluate alternative pollution control scenarios, and to prioritize (spatially) where watershed management activities need to focus to most effectively achieve watershed management goals and utilize limited resources most effectively. Models can also be used to assess risks and provide information to stakeholders about the benefits and consequences of not achieving selected watershed management goals. A previous ASABE collection of articles on TMDL modeling tools (MuÒozCarpena et al., 2006) provides in-depth articles that review models and modeling techniques to simulate sediment and nutrients (Borah et al., 2006), pathogens (Benham et al., 2006), dissolved oxygen (Vellidis et al., 2006), and biological indicators (Yagow et al., 2006) as well as model uncertainty (Shirmohammadi et al., 2006) and application of model results to economics (Bosch et al., 2006). The articles in the current collection (summarized subsequently) provide model applications that build on these fundamental concepts.

Jiang et al. (2011), in the article "Modeling the water balance processes for understanding the components of river discharge in a non-conservative watershed," investigate a modification to the Soil and Water Assessment Tool (SWAT) model to account for external subsurface flow into a watershed in a karst region in eastern Japan. The authors refer to the external subsurface inflow as indicative of a nonconservative watershed because the water balance typically represented in rainfall-runoff models does not represent the underground fluxes that cause a system to lose or gain water from outside the topographic watershed boundaries. This study describes one approach to representing an underground water flux by treating it as a point-source input. The results indicate that the underground water influx accounted for $47 \%$ of streamflow during the study period. The authors conclude that the simulated daily baseflow, monthly streamflow, surface runoff, and evapotranspiration (ET) all showed good agreement with the corresponding observations, and that their approach succeeds in reasonably simulating streamflow in the study watershed. The simulation of daily streamflow with this modification produced coefficient of determination $\left(\mathrm{R}^{2}\right)$ values of 0.65 during calibration and 0.66 during validation.

Pai et al. (2011), in the article "Identifying priority subwatersheds in the Illinois River drainage area in Arkansas using a distributed modeling approach," describe an application of SWAT to identify the 12-digit hydrologic unit code (HUC) subwatersheds that contribute larger amounts of sediment, total phosphorus, and nitrate-nitrogen in the $1,960 \mathrm{~km}^{2}$ Illinois River (Arkansas) basin. Model calibration was performed at multiple stations distributed throughout the drainage area (seven for streamflow; three for water quality), and the SWAT2009 land use change module was used to incorporate annual land use change based on five land use scenarios over a 13-year period. Model calibration and validation were performed on annual surface, base, and total flow volumes and sediment, total phosphorus, and nitratenitrogen unit-area loads using multiple objective functions to evaluate model performance: percent relative error (RE), Nash-Sutcliffe coefficient of model efficiency (NSE), percent bias (PBIAS), $\mathrm{R}^{2}$, and the ratio of root mean square error to standard deviation (RSR). This modeling study illustrates that characterizing land use change is important in accurately calibrating watershed parameters and that spatial diversity can best be represented through multi-point calibration. The resulting subwatershed prioritizations revealed that selected watersheds generated higher loads of all three pollutants, indicating areas where stakeholders should focus pollution control efforts to address water quality issues while optimizing limited resource allocation.

Sexton et al. (2011), in the article "A stochastic method to characterize model uncertainty for a nutrient TMDL," address the issue of model uncertainty when using a watershedscale water quality model to quantify TMDL target nutrient loads. The authors demonstrate a procedure for assessing the level of confidence of meeting a specific water quality standard when achieving a given TMDL target pollutant load. Because TMDLs are developed for a single load value, the implied risk of not achieving that target load and thus not achieving the water quality standard has been ignored, despite repeated calls from the scientific community for this kind of risk assessment and uncertainty estimate (e.g., Shirmohammadi et al., 2006). This study on Warner Creek in the Maryland Piedmont used the mean-value first-order reliability method (MFORM) paired with a stochastic approach and the SWAT model to provide a formal procedure for quantifying an explicit TMDL margin of safety (MOS) by assessing the risk of not achieving the TMDL target load or water quality standard.

Diaz-Ramirez et al. (2011), in the article "Analysis of hydrological processes applying the HSPF model in selected watersheds in Alabama, Mississippi, and Puerto Rico," use the Hydrological Simulation Program - FORTRAN (HSPF) to gain insights into the hydrological processes in three different watersheds: upland basins in Alabama and Mississippi (1,856 $\mathrm{km}^{2}$ Luxapallila Creek), a humid subtropical watershed in coastal Alabama (140 $\mathrm{km}^{2}$ Fish River), and a steepslope tropical catchment in Puerto Rico $\left(99 \mathrm{~km}^{2}\right.$ Rio Caonillas). The authors reviewed the literature for parameter value ranges, both evaluated from physical data and calibrated, for comparison with the results of their study. They then identified flow stations with observed data for comparison with simulated results and identified a number of measures to test the effect of their simulations using separate time periods for calibration and verification. Model creation within HSPF was performed within the BASINS interface to illustrate how watersheds could be characterized with existing data and databases internal to BASINS. The methods followed were similar to those that practicioners using HSPF (or any model for that matter) would follow as they prepare to 
model the fate and transport of a given pollutant within an impaired watershed. The results of this research illustrate that HSPF adequately simulated the hydrology of the drastically differing watersheds (small catchments vs. large basins, flat vs. hilly areas, low vs. moderate/high runoff potential, and tropical marine vs. humid subtropical climates).

Sheshukov et al. (2011), in the article "Seasonal and annual impacts of climate change on watershed response using an ensemble of global climate models," develop and assess a method to downscale monthly global climate model (GCM) temperature and precipitation data to drive a daily hydrologic model. A stochastic weather generator (WINDS) was used to develop daily input data for hydrololgic simulation in SWAT2005 by combining statistical distributions of sitespecific historical daily weather data with an ensemble of monthly climate change projections from 15 GCMs. This method captured "internally generated" (e.g., convective) storms missed by GCMs while reflecting the monthly regional shifts simulated by the GCMs. The authors found that seasonal hydrologic response was impacted interactively by shifts in both precipitation and temperature; for example, increased precipitation coupled with increased temperature (and evapotranspiration) led to decreased streamflow as well as longer summer drought. An important conclusion of the study is that modeling analyses of climate change based on precipitation shifts alone or by analysis of annual hydrologic responses alone, which are both common approaches reported in the literature, may not reflect adequately the severity of hydrologic impacts on drought, flood, or other watershed responses. Future modeling efforts to inform watershed management planning must consider uncertainty and variability in climate change scenarios (and climate models) as well as the resulting impacts that hydrologic response have on management measure effectiveness.

\section{Monitoring AND Assessment}

Monitoring and assessment activities are fundamental to watershed management planning and execution. Accurate and adequate (spatial and temporal) monitoring is necessary in all phases of watershed management. The articles in this collection that deal with monitoring and assessment illustrate the critical role of monitoring and assessment in all phases of watershed management, from watershed and pollutant source characterization to assessing the effectiveness of pollution control measures.

Reuben et al. (2011), in the technical note "Pineview Reservoir phosphorus loading, unloading, and the role of groundwater in the estimates," highlight the limitations of the "sparse" data used to develop the nutrient (N and P) TMDL for the Pineview Reservoir in Utah. The Pineview Reservoir TMDL was developed using existing data in 2002. Subsequent questions about the TMDL led to more extensive monitoring of the reservoir to better characterize both $\mathrm{N}$ and $\mathrm{P}$ loading and $\mathrm{N}$ and $\mathrm{P}$ cycling within the reservoir. Monitoring for this study included collecting grab samples within the reservoir and high-frequency monitoring of both groundwater and surface water inflows to the reservoir. This monitoring improved the understanding of internal nutrient processing within the reservoir and permitted a more accurate characterization of nutrient loading to the reservoir. This characteriza- tion in turn provided an improved understanding of the partitioning of $\mathrm{N}$ and $\mathrm{P}$ loading between groundwater and surface water. The results indicated that shallow groundwater loading of dissolved $\mathrm{N}$ and soluble reactive $\mathrm{P}$ are lower than the estimates used in the TMDL and that both $\mathrm{N}$ and $\mathrm{P}$ loading from surface water are higher than was estimated when the TMDL was initially developed. This study illustrates the iterative nature of the TMDL process and the importance of limited additional monitoring to identify and refine both identified and suspected pollutant sources.

Ibekwe et al. (2011), in the article "Variations of indicator bacteria in a large urban watershed," investigated the factors associated with high fecal indicator bacteria counts in the Santa Ana River watershed in southern California. Thirteen sites were sampled over a range of flow conditions to examine spatial and temporal bacteria concentrations. The authors used an analysis of covariance to test for effects of site, water flow conditions, and water quality covariates. Their findings showed that the control site and a wastewater treatment plant site showed significantly lower indicator bacteria concentration than sites influenced by urban runoff and agricultural activities. These results, among others, imply that total fecal indicator bacterial counts in the Santa Ana River watershed were influenced by spatial location effects more strongly than other effects. Findings from this study will supplement the existing information that is used by modelers to more accurately characterize pollutant sources and critical streamflow conditions in urban watersheds.

Ice (2011), in the technical note "Assessing best management practices effectiveness at the watershed scale," summarizes and compares different approaches for evaluating the effectiveness of BMPs for controlling nonpoint sources of pollution. He illustrates how various pollution reduction goals and BMP effectiveness measures can be applicable within a given context and how different assessment approaches can present different pictures of performance. The author argues that the three biggest challenges for assessing BMPs directed at nonpoint-source pollution control are defining appropriate water quality expectations, determining what site conditions limit BMP effectiveness, and determining specific watershed metrics and appropriate spatial and temporal scales for assessment. The author used forested watershed studies to illustrate why he believes a weight-ofevidence approach may be the most useful way to judge BMP effectiveness.

Endale et al. (2011) in the technical note "Difficult lessons learned in measuring flow on small watersheds," document the travails of using submersible pressure transducers to measure flow level (stage) and estimate flow in a small research watershed in Watkinsville, Georgia. They highlight the need for regular transducer calibration to adjust for sensor drift and provide a list of best practices that should be followed to ensure the highest confidence in the monitoring data collected using similar technology. The experience detailed in this technical note illustrates that all data used for watershed management assessment and planning purposes should be evaluated before use. Were the data collected using standard or accepted protocols? Were the data subjected to sufficiently rigorous QA/QC checks? The authors conclude that the use of suspect data will lead to incorrect conclusions about the system being monitored, which can lead to erroneous watershed management planning decisions. 


\section{Summary AND CONClusions}

While holistic watershed management should include broad stakeholder engagement to aid in defining specific watershed management goals, setting those watershed management goals and assessing attainment of those goals must be based on the application of sound science and appropriate tools and technology. The articles in this collection contribute to the body of literature that seeks to inform and advance sound watershed management planning and execution. The conferences where the articles in this collection were first presented illustrate the broad range of topics encompassed by holistic watershed management planning, including pollution control method development and assessment, pollutant source and watershed characterization, pollutant fate and transport modeling, modeling uncertainty, economic cost/ benefit analysis, policy and regulation, and watershed management case studies. The articles included in this collection reflect that topical breadth.

\section{ACKNOWLEDGements}

This article introduces the nine articles in the ASABE 2011 Watershed Management Special Collection in this issue of Transactions of the ASABE (six articles) and the concurrent issue of Applied Engineering in Agriculture (three articles). The authors wish to thank the ASABE publications staff, associate editors, and reviewers for their contributions to and timely management of the review process, and the authors and co-authors of the articles in this collection for their contributions to the research literature represented by this collection.

\section{REFERENCES}

Benham, B. L., C. Baffaut, R. W. Zeckoski, K. R. Mankin, Y. A. Pachepsky, A. M. Sadeghi, K. M. Brannan, M. L. Soupir, and M. J. Habersack. 2006. Modeling bacteria fate and transport in watersheds to support TMDLs. Trans. ASABE 49(4): 987-1002.

Benham, B., L. Krometis, K. Kline, T. Dillaha, and G. Yagow. 2011. Applications of microbial source tracking in the TMDL process. In Microbial Source Tracking: Methods, Applications, and Case Studies. New York, N.Y.: Springer.

Borah, D. K., G. Yagow, A. Saleh, P. L. Barnes, W. Rosenthal, E. C. Krug, and L. M. Hauck. 2006. Sediment and nutrient modeling for TMDL development and implementation. Trans. ASABE 49(4): 967-986.

Bosch, D. J., C. Ogg, E. Osei, and A. L. Stoecker. 2006. Economic models for TMDL assessment and implementation. Trans. ASABE 49(4): 1051-1065.

Diaz-Rameriz, J., W. McAnally, and J. Martin. 2011. Analysis of hydrological processes applying the HSPF model in selected watersheds in Alabama, Mississippi, and Puerto Rico. Applied Eng. in Agric. 27(6): 937-954
Endale, D., D. Fisher, M. Jenkins, and H. Schomberg. 2011. Difficult lessons learned in measuring stage and flow rate on small watersheds. Applied Eng. in Agric. 27(6): 933-936.

EPA. 1991. Guidance for water quality-based decisions: The TMDL process. EPA 440/4-91001. Washington, D.C.: U.S. Environmental Protection Agency, Office of Water.

EPA. 2008. Handbook for developing watershed plans to restore and protect our waters. EPA841-B-08-002. Washington, D.C.: U.S. Environmental Protection Agency, Office of Water.

EPA. 2011. Fact sheet: Total maximum daily loads. EPA841F-10-001. Washington, D.C.: U.S. Environmental Protection Agency, Office of Water. Available at: www.epa.gov/owow/ tmdl/results/pdf/tmdl_progress_fact_sheet.pdf. Accessed 5 October 2011.

Ibekwe, A. M., S. M. Lesch, R. M. Bold, M. B. Leddy, and A. K. Graves. 2011. Variations of indicator bacteria in a large urban watershed. Trans. ASABE 54(6): 2227-2236.

Ice, G. 2011. Technical note: Assessing best management practices effectiveness at the watershed scale. Applied Eng. in Agric. 27(6): 925-931.

Jiang, R., Y. Li, Q. Wang, K. Kuramochi, A. Hayakawa, K. Woli, and R. Hatano. 2011. Modeling the water balance processes for understanding the components of river discharge in a non-conservative watershed. Trans. ASABE 54(6): 925-931.

Muñoz-Carpena, R., G. Vellidis, A. Shirmohammadi, and W. W. Wallender. 2006. Evaluation of modeling tools for TMDL development and implementation. Trans. ASABE 49(4): 961965.

Pai, N., D. Saraswat, and M. Daniels. 2011. Identifying priority subwatersheds in the Illinois River drainage area in Arkansas using a distributed modeling approach. Trans. ASABE 54(6): 2181-2196.

Reuben, T., B. Worwood, L. Carrigan, and D. Sorenson. 2011. Pineview reservoir phosphorus loading, unloading, and the role of groundwater in the estimates. Trans. ASABE 54(6): 22192225.

Sexton, A., A. Shirmohammadi, A. Sadeghi, and H. Montas. 2011. A stochastic method to characterize model uncertainty for a nutrient TMDL. Trans. ASABE 54(6): 2197-2207.

Sheshukov, A. Y., C. B. Siebenmorgen, and K. R. Douglas-Mankin. 2011. Seasonal and annual impacts of climate change on watershed response using an ensemble of global circulation models. Trans. ASABE 54(6): 2209-2218.

Shirmohammadi, A., I. Chaubey, R. D. Harmel, D. D. Bosch, R. Muñoz-Carpena, C. Dharmasri, A. Sexton, M. Arabi, M. L. Wolfe, J. Frankenberger, C. Graff, and T. M. Sohrabi. 2006. Uncertainty in TMDL models. Trans. ASABE 49(4): 1033-1049.

Vellidis, G., P. Barnes, D. D. Bosch, and A. M. Cathey. 2006. Mathematical simulation tools for developing dissolved oxygen TMDLs. Trans. ASABE 49(4): 1003-1022.

Yagow, G., B. Wilson, P. Srivastava, and C. C. Obropta. 2006. Use of biological indicators in TMDL assessment and implementation. Trans. ASABE 49(4): 1023-1032. 